\title{
The Man Who Comes after; or, Careful How You Curate
}

\author{
JAMES B. GRIFFIN \\ Museum of Anthropology \\ University of Michigan \\ Ann Arbor, Michigan 48109
}

$\mathrm{T}$

HE TITLE of my presentation derives from a comment made to me in the summer of 1934 by Clifford C. Anderson, who at the time owned a portion of the narrow flood plain along the Little Miami River below the northwest part of Fort Ancient in Warren County, Ohio. He also owned a small museum building in which he installed exhibits of burials, and of his other finds from the prehistoric village that he had excavated over a number of decades. Anderson as a young man had been hired as a laborer by W. K. Moorehead for the excavations made at Fort Ancient in the fall of 1891 for the World's Columbian Exposition in Chicago. He then went to the Hopewell site with Moorehead's crew, and later conducted excavations for the Robert S. Peabody Foundation in northeastern Arkansas and in southwestern Indiana. By the time I arrived at his door to study the material he had collected, Anderson had slackened his excavation activities and spent most of his time maintaining the museum from which he obtained a small income.

Anderson felt that his work of gathering and preserving the data from the village was largely unappreciated by the archaeological community and he was therefore pleased to have his materials studied and the results published. He called me "the man who comes after" because the results of his labors were at last to become part of the archaeological literature and interpreted as a part of the growing knowledge of American prehistory. It was his fond hope that his collection would be acquired by the Ohio Historical and Archaeological Society and be preseved for posterity by means of exhibits and continuing study. Following acquisition by the state the collection was given additional study by Richard G. Morgan, Curator of Archaeology in the 1940s and by Patricia Essenpreis in the early 1970s. Some of Anderson's collection is on exhibit in the small 
museum at Fort Ancient and the bulk of it is, I presume, in the Ohio Historical Center in Columbus. The skeletal material from Anderson's excavations were studied by Georg K. Neumann and formed a major part of his Lenapid physical type, which he attributed to the Central Algonquin Indians. His measurements and observations were later incorporated by Louise Robbins, with her own studies, into a major monograph on the peoples of the Fort Ancient culture (Robbins and Neumann ${ }^{1}$. And so it is that "the man who comes after" and carries on the work of the excavator in recovering data on the past, is followed by others who came after and improve on the earlier studies. They bring new problems, new techniques and often more adequate funds for the continuing studies, if the material excavated has been adequately curated.

This brings me to an example of attrition of one of the most valuable collections ever made in a single excavation from a site in the eastern United States. When Moorehead, while working at Fort Ancient, was chided for not obtaining material worthy of exhibit at Chicago, he and his crew moved to the Hopewell site in Ross County, Ohio, where they worked from late October 1891 to about the end of January 1892. Following the excavations, the materials were shipped to Cambridge, then at least some part of them was sent to Chicago for the exhibition. Following the exhibition, the specimens were returned to Cambridge where George Owen Dorsey was scheduled to prepare a report on Moorehead's excavations, but for whatever reasons did not do so. The collection was then returned to the Field Museum in Chicago for permanent custody.

Moorehead published a number of reports on the Hopewell site around the turn of the century, and Charles $C$. Willoughby studied some of the material and published a number of papers on the art work. The Field Museum published a short report on the Hopewell site and its material in 1922 based on Moorehead's field notes and reports. In one of our conversations in the late 1920s or early 1930s Ralph Linton told me he had put the report together. The Hopewell collection was catalogued over the years and some person or persons in the early part of the century spent a considerable amount of time repairing many of the obsidian knives and spears from Altar 2 of Mound 25.

By at least the 1920s what might be called the historic Hopewell Interaction Sphere was initiated, for the Hopewell collection at the Field Museum was a gold mine which was mined over some number of years to obtain specimens of more interest to the several curators. $\mathrm{H}$. C. 
Shetrone excavated at the Hopewell site in the mid-1920s, but did not obtain a number of items that Moorehead had recovered. Since Shetrone obtained what he regarded as duplicate specimens from his excavations he made an exchange in April 1925 with the Field Museum to obtain some of Moorehead's. This, at least, had the virtue of returning them to Ohio and made Shetrone's report more valuable and the exhibits more attractive in the Ohio State Museum. In May of 1931, an exchange was made of specimens from the Hopewell collection including a copper axe, copper plates, copper ear spools, and some of the repaired obsidian spears and knives for a collection of Southwestern pottery vessels under the control of Donald O. Boudeman of Kalamazoo. Boudemann had a loose connection with the Kalamazoo Public Museum, but he was also a well-known collector and dealer. The obsidian specimens, and probably the other items as well, went into the collectors-dealers market and their commercial value was enhanced by the Field Museum catalogue numbers, which were left on the specimens. It is not known accurately how many obsidian artifacts were in the Altar 2 deposit, nor do I know how many whole and fragmented pieces are now in Chicago. It might still be possible for a lithic analyst to make a shrewd judgment, from the distinctive techniques of manufacture, as to whether the remaining ones are the product of a single Hopewell flint knapper. Some years ago as a part of trace element studies at the University of Michigan we borrowed some of the obsidian specimens and determined that in all probability the Hopewell obsidian was obtained from Yellowstone Park deposits.

Additional depletion of the Hopewell collection took place in November 1932, when Byron Knoblock, a well-known Illinois wheeler and dealer in antiquities, obtained specimens. So did the National Museum of Mexico in 1934, along with South Pacific ethnographic material, in exchange for Mexican prehistoric artifacts to be used primarily for exhibit. Other exchanges were made with the Milwaukee Public Museum and the R. S. Peabody Foundation of which Moorehead was the Director. At least one object, a copper celt with meteoric iron adhering to it, was sold. A side effect of the Mexican exchange was that it furnished justification to certain groups in Mexico to remove Rubin de la Borbolla as the Director of the National Museum on the ground that he had dissipated some of Mexico's priceless heritage. No one at the Field Museum was removed or even criticized for these transactions.

While Moorehead is not known as a careful excavator and preserver of ceramic specimens from the fill of mounds or of whole vessels that might have survived more careful recovery techniques, some small 
amount of pottery was in the Field Museum. It had survived the four long-distance shakedown shipments mentioned earlier and is now deposited in the Museum of Anthropology of the University of Michigan through an arrangement with one of the former Curators of the Field Museum. There are other preserved instances of the decline of the Hopewell collection, but it should be evident that present and future studies of the so-called Hopewell Interaction Sphere of prehistoric times have been severely hampered by the historic trade and exchange, which latter was also done for personal gain, achieved status, and the acquisition of exotic goods.

Some six miles south of the Field Museum is the University of Chicago, which is well known as a leading educational institution devoted to the preservation of man's cultural heritage and to its increase through scholarship, scientific investigations, and academic freedom for its faculty and in its training of students. In 1923 Fay Cooper Cole left the Field Museum to become an Assistant Professor of Anthropology at the University of Chicago and developed over the years a program of archaeological research, primarily within Illinois, which received a considerable amount of national and even international applause. This program of graduate training in Midwestern archaeology lasted for a little over 20 years until Cole retired in 1947. The program was carried on for only a short time afterwards. In order to support the large number of students attracted to Chicago, Cole procured funds from foundations and private donors; some of this money was set up in funds that provided support for the extensive excavations in Fulton County and at the Kincaid site, to mention only two locations. In addition, the Department of Anthropology of the University of Chicago acquired materials from a sizeable number of responsible amateur archaeologists, like George Langford of Joliet who donated the Fisher and Adler collections, because these nonprofessionals were persuaded that their acquisitions would be preserved for posterity at the University instead of being dissipated and destroyed. The several acquisitions forced Cole to acquire space to house them and to arrange for their cataloguing, for Cole had been a Field Museum Curator for some seventeen years before he took the Chicago post. However, after Cole retired the archaeological program in the state came under attack by his friends and colleagues in the Department on the grounds that it had really not been very good, was not problem-oriented, and that a great private institution like the University of Chicago should not be engaged in Midwestern archaeology when there were more glamorous activities abroad and the space occupied by the collections 
was needed by more worthy programs. One of the main "problems" of this movement was to get control of Department research funds so that they would no longer be wasted on Midwestern archaeology. One of the results was the dispersion of the collections to institutions where it was assumed they would be given reasonable care. But the inevitable result has been breakage, lost notes, and misplaced specimens so that to check on statements or interpretations made in the published reports or notes is now extremely difficult or impossible. I remember hearing rumors that the University of Michigan was trying to obtain all or most of the collections, but we did not receive any of them. This University of Chicago example is not an isolated or unusual case. When archaeological or other scientific collections in the control of museum or University departments are obtained through the special efforts of one or more staff members, the collections are ignored, gradually deteriorate, or are disposed of when those staff members have gone.

Another example of somewhat callous curation is a part of the Clarence B. Moore saga. For some thirty years Moore supported and conducted excavations in the Southeast. Most of his better preserved specimens were turned over to the Academy of Natural Sciences of Philadelphia and Moore paid for the preparation and publication of a remarkable series of almost yearly reports from 1894 to 1918. Not only did the Academy receive collections but Moore presented whole vessels and other items to the Peabody Museum at Harvard, the Peabody Foundation of Andover and the Buffalo Museum of Science. It is likely that the American Museum of National History and the U.S. National Museum, among others, also benefited from his largess. Most of the Moore Academy collection was purchased by George G. Heye in 1929 and is in the Museum of American Indian, Heye Foundation (Wardle ${ }^{2}$ ). The collections have since been studied by quite a few archaeologists, incorporated into a number of reports, and been in a number of exhibitions. It would have been far better, however, if a single institution could have received and adequately preserved the entire Moore collection so that successive generations of archaeologists with new problems and the techniques to solve them could have studied the materials.

The various government agencies that sponsored relief labor archaeology in the East from about 1933 to 1941 excavated hundreds of archaeological sites and recovered an enormous amount of material. This program has been justly and unjustly criticized for sins of commission and omission. It produced an impressive number of monographs, papers and statements, and resulted in important contributions to the 
chronological framework and prehistoric cultural descriptions and distributions for most of the eastern United States. In some cases these collections have been reasonably well maintained and have formed an important part of continuing archaeological studies. Notable among these collections are the one at the University of Tennessee at Knoxville, the Alabama materials housed at Moundville, and the Spiro collection at the University of Oklahoma. I have the unhappy feeling that many contract archaeology programs of the recent past, and now being carried out, do not have an adequate support base for the proper preservation and curation of the materials and data recovered. This will inevitably hamper the scholars of the future with their new analytical techniques and new problem orientations.

Excavated materials are gathered after a considerable expenditure of time and money and this cost makes for wasteful careless curatorial care. Even if an adequate report is prepared and published, it will only be satisfactory for a relatively short time. Not only should the specimens be preserved and identified as to location and association, but the field notes must be available in order to provide the bits of information recorded during the field work that are inevitably missing in published reports. Most museum catalogues do not provide adequate data for satisfactory interpretations and an associated accession file with such field or background data is necessary.

In the years of my work in archaeology, I have obtained much of the data I have used from museum and private collections. I have benefited from at least 96 museums or institutionally supported collections and a minimum of 28 private collections in the United States and Canada. In Mexico I worked with four state and national collections, but for the Valley of Mexico I found I had to depend on the material I collected myself. In Europe I worked in eight countries and in 19 museums or institutes. These preserved materials from earlier surveys and excavations provided me with information for a large majority of the papers I have had published. In most instances, it was difficult or impossible to apply the conjunctive approach or to ascertain the temporal placement of the specimens. There were no indications of locations within or outside of house floors, identification of position within site boundaries, or indications of pit or dump heap recovery. But, in many instances exiguous data did provide valuable information on geographical distribution and site locations, local and areal regions of high concentration of identifiable complexes, and the character and composition of the cultural remains. Many radiocarbon dates were run on specimens in museum collections, 
particularly in the early days. Museum or institutional collections have been extensively used for trace element studies of copper, obsidian, and galena in order to provide firm identification of sources and probable trade routes. In the mid-1930s I received a small amount of pottery from Glenn A. Black's excavation of the Nowlin mound, a late Adena site in southeastern Indiana. At the time the Adena culture was regarded as a nonceramic complex. Subsequently in 1936, I recognized similar pottery in the U. S. National Museum and in the Peabody Museum-Harvard University from mounds that had been excavated in the late 1800s. These identifications helped to provide recognition of Adena as a regional expression of Early Woodland. Recognition and identification of the Goodall complex of western Michigan of Middle Woodland was based on the collections, largely made in the late 1800 s, in the Grand Rapids Public Museum.

One of the best examples of convergence in cultural behavior, without much possibility of the behavior having been stimulated by diffusion, is that of the use of shoe boxes to store sherds and other collectibles at Louisiana State University in the late 1930s. I do not know where James A. Ford got the idea and I am sure I saw such practices in other Southeastern centers perhaps stimulated by him. Shoe boxes were in good supply, cheap, and available at many outlets. From 1953 to 1971 I worked in or visited quite a number of museums and institutes in Europe but only when I went to the Institute of Archaeology in Leningrad in 1961-62 did I see shoe boxes with sherds and other items from Okladnikov's Siberian collections. They filled shelves and were stacked around the periphery of the room with very little room to maneuver. I know of no way that Okladnikov could have obtained the idea from Ford or vice versa. Certainly shoe boxes are well known in the Soviet Union, relatively cheap, and easily accessible. They also, like the boxes in the United States, have lids which not only serve to keep the pottery clean but also allow the boxes to be stacked. Such curatorial practices, however, often result in the deterioration of the boxes from the weight of others piled on top of them.

While there are many difficulties associated with the reexcavation of museum collections, there are also some advantages. Instead of the usual summer heat or spring and fall cold seasons encountered in field work, museum study is done in a building that usually provides more equitable temperatures and access to a variety of facilities and conveniences that are often missing in a field situation. Museums are normally located in an urban environment which provides many opportunities for welcome 
diversions in nonworking hours. They usually have some degree of permanence, at least the buildings do, and one can be fairly confident that collections reported to be housed at a particular location will still be there. They may be dirty, difficult to find, and perhaps even unwashed, but they are available.

One of the major problems affecting the proper curation of specimens is that most museums or institutions have not had the facilities and manpower to provide adequate care. Too often museums are valued as locations where specimens or concepts can be exhibited to the public. Research funds, when available, are heavily weighted toward field work, with laboratory analysis and publication usually receiving a mouse's share. Adequate curation in terms of restoration, preservation, proper cataloguing, and storage are barely supported at all. Recently there has been some support by the National Science Foundation and the National Endowment for the Humanities for alleviating the curatorial disasters of past. The Interagency Archaeological Services program has made a strong effort to bring to the attention of university and museum administrators their responsibility to provide satisfactory curatorial facilities for materials gathered by federally supported projects. The Anthropological Services unit of the American Anthropological Association sponsored a study of the curation and management of archaeological collections (Lindsay and Williams-Dean ${ }^{3}$ ), but this has not received wide distribution. The Council for Museum Anthropology sponsored by the National Science Foundation published a report on the value of institutional research collections (Ford ${ }^{4}$ ). This conference on the research potential of anthropological museum collections is a further indication of the growing recognition of the usefulness of collections to the ongoing research activities of contempory scholars.

An example of unfortunate treatment of collections is provided by a mid-south university that had a good reputation for issuing reports on the W. P. A. excavations. However, space for storage was normally inadequate so that, probably under pressure, the animal skeletal material from one of the well known Late Archaic sites was ground up for bone meal and spread over the Chairman's lawn. While a report was issued identifying the species present, one would expect that restudy today would produce much more information. In 1947 and 1948 the Museum of Anthropology at the University of Michigan excavated the multicomponent Snyders village site in Calhoun County, Illinois. Bone preservation was excellent and catalogued by square and depth. Bone artifacts were selected and identified by personnel of the Museum of Zoology. 
The nonartifactual animal bone however, was sent to a midwestern university for identification. Quite a few years passed before we were again alerted to the absence of this material. During that time the collection was dissipated, and practically no record remained of the species or individual parts that had been examined for they were used for course work!

I recently learned that the Ethnographic Department of the Danish National Museum in Copenhagen had completed and published a record of its collections from the beginning of their existence and that all of the specimens were identified during the several years that the compilation took place. There are relatively few institutions in the United States that could successfully make such a study and achieve such excellent results.

This paper has emphasized the continuing value of collections for future generations to reinterpret and augment the contribution they make to our understanding of the past. It has given examples where unfortunate care of collections has seriously impaired their value, and the ones cited could be duplicated by many others. It has suggested that historically there has been relatively little financial support for curatorial activities because there has been little recognition of the vital importance of such work, not only on the part of administrators, but by the professional archaeologists who have recovered the specimens.

\section{REFERENCES}

1. Robins, L. \& G. K. Neumann. 1972. The Prehistoric People of the Fort Ancient Culture of the Central Ohio Valley. Anthropological Paper 47, Museum of Anthropology University of Michigan, Ann Arbor.

2. WARDLE, H. N. 1929. Wreck of the archaeological department of the Academy of Natural Sciences of Philadelphia. Science 70: 119-121.

3. Lindsay, A. J. \& G. Williams-Dean. 1979. The Curation and Management of Archaeological Collections: A Pilot-Study. Anthropological Research Services, American Anthropological Association, Washington, D.C.

4. Ford, R. I. 1979. Systematic Research Collections in Anthropology: An Irreplaceable National Resource. Peabody Museum, Harvard University, for the Council for Museum Anthropology. Cambridge, MA. 